BULLETIN Bulletin hispanique

HISPANIQUE Université Michel de Montaigne Bordeaux

117-1 | 2015

Les poètes des rhéteurs

\title{
De cambios estilísticos y paradigmas retóricos
}

Bizantinistas y antihermogénicos

\section{Elena Artaza}

\section{(2) OpenEdition}

Journals

Edición electrónica

URL: https://journals.openedition.org/bulletinhispanique/3827

DOI: 10.4000/bulletinhispanique.3827

ISSN: 1775-3821

Editor

Presses universitaires de Bordeaux

\section{Edición impresa}

Fecha de publicación: 1 junio 2015

Paginación: 11-24

ISBN: 979-10-300-0174-7

ISSN: 0007-4640

Referencia electrónica

Elena Artaza, «De cambios estilísticos y paradigmas retóricos», Bulletin hispanique [En línea], 117-1 |

2015, Publicado el 01 junio 2018, consultado el 12 febrero 2022. URL: http://journals.openedition.org/ bulletinhispanique/3827 ; DOI: https://doi.org/10.4000/bulletinhispanique.3827 


\title{
De cambios estilísticos y paradigmas retóricos. Bizantinistas y antihermogénicos
}

\author{
Elena Artaza \\ Universidad de Deusto - Bilbao - España
}

Le présent travail a pour objet de montrer l'importance des doctrines hermogéniennes sur le style dans les traités de rhétorique du Siècle d'Or, ainsi que leur diffusion dans les manuels d'enseignement, et de déterminer la portée réelle de ces théories dans le domaine de la prédication et de la création littéraire.

Mots-clés : traités de rhétorique, doctrine de style, hermogénisme.

Este trabajo se ocupa de la importancia y vigencia en el panorama de las retóricas áureas de las doctrinas hermogénicas sobre los diferentes estilos y su difusión en los manuales de enseñanza para valorar cuál pudo ser el alcance real de la influencia de estas teorías en la predicación o en la literatura.

Palabras claves: retóricas de los Siglos de Oro, teorías sobre los estilos, hermogenismo.

This paper deals with the importance of the Hermogenic doctrines about diverse styles, in the Spanish Golden Age treatises on rhetoric, and with their diffusion in the handbooks about this topic. This paper also aims at assessing what might have been the real extent of the influence of these theories in areas such as preaching or literature.

Keywords: Golden Age Treatises on Rhetoric, Theories on the Styles, Hermogenism.

Si algún tema ha hecho correr tinta en los estudios áureos, ha sido el de los cambios de estilo que, tanto en la prosa como en la predicación, se aprecian en las postrimerías del siglo XVI y en las primeras décadas del Seiscientos. Son 
numerosos los trabajos ${ }^{1}$ y de sobra conocidos como para llevar a cabo un repaso de todo lo afirmado en ellos.

Pero todo cambio tiene sus causas y sus condiciones previas que lo hacen posible: renacen y se ponen de moda nuevos modelos literarios a imitar y, sobre todo, surgen nuevos paradigmas y corrientes en las poéticas y retóricas que el orador o el poeta debían seguir.

El presente artículo solo pretende arrojar un poco de luz en el panorama de las corrientes retóricas de la época citada: establecer cuántas se pueden distinguir, en qué se diferencian, qué maestros las explican y defienden como más útiles para la enseñanza, en qué autoridades clásicas se apoyan y quiénes las desprecian y consideran tan farragosas como poco rentables en la docencia de los jóvenes.

La primera corriente que podemos identificar entre nuestros retóricos es la llamada clasicista. Sus autores siguen fundamentalmente las doctrinas de Aristóteles y más aún las de Cicerón, la Rhetorica ad Herennium y las Institutiones del hispanolatino Quintiliano.

Es más que conocida la estructura característica de estas obras, así como el contenido de su doctrina en las distintas etapas elaborativas del discurso. Son archisabidas las recetas para la captatio attentionis, bevolentiae et docilitatis en el exordio; y también la preceptiva de la narración y, sobre todo, las normas para conseguir sus cualidades: la brevedad, claridad y verosimilitud. Lo son igualmente las teorías acerca de la argumentación con sus argumenta a persona o a re, y sus sedes, o loci, como fórmulas para construir los argumentos. Es casi un tópico que estos lugares podían ser tanto inherentes o vinculados al asunto mismo del que se trata -según decía Cipriano Suarez-, como remotos o alejados de la quaestio. Los loci inherentes eran dieciséis y los extrínsecos a la causa menores en número, pero debían examinarse oportunamente para conseguir la utilitas de la causa. Formaban parte de este grupo las autoridades citadas, los testimonios, las sentencias precedentes, etc.

En la doctrina elocutiva, eran características de esta corriente, en primer lugar, la preceptiva para conseguir las virtutes elocutionis (la latinitas, la perspicuitas y el ornato con sus correspondientes figuras) y sobre todo la delimitación de los estilos elocutivos en tres: humilde, medio y sublime (o ático, rodio y asiático).

No considero necesario repetir aquí tan célebres enseñanzas, pero sí recordar que a lo largo del XVI se adscribieron a esta oleada autores y maestros de retórica tan importantes como Nebrija, cuya retórica, publicada en Alcalá en 1515, tal como reza su título y advierte el autor en la introducción, no se aparta en absoluto de las doctrinas de los grecolatinos; Fray Miguel de Salinas (1541), que escribe su retórica en lengua castellana para uso de los novicios jerónimos que no dominan el latín; y Alfonso García Matamoros, también profesor de Alcalá y cuya última obra, De tribus dicendi generibus de 1570,

1. Sin ser exhaustivos, citamos como muestra los trabajos recogidos en López Grigera (1994: 69-83, 121-139 y 141-150); Mañero (2009); Blanco (2006); Cerdán (1993); García Rodríguez (2002); Martín Jiménez (2000); Egido (1986); Isasi Martínez (1997). 
reviste, como veremos enseguida, un interés especial por lo que respecta a la polémica antihermogenista.

Milita también en esta corriente Juan Lorenzo Palmireno (Gallego Barnés 1982), ciceroniano furibundo, que publica en 1560 en Zaragoza su De vera et facile imitatione Ciceronis. El maestro de Alcañiz, aragonés de nacimiento, enseñó en Valencia y, aunque publicó los Progymnasmata de Aftonio en 1552, fue una rara avis en el panorama de la docencia retórica levantina. Asensio, en un trabajo imprescindible para conocer la polémica entre los partidarios de Cicerón y la moderación y sencillez en el estilo que propugnaba Erasmo (Asensio 1978), menciona una carta de Palmireno en la que agradece a Honorato Juan que hubiera introducido en el ciceronianismo a autores como Andrés Sempere y Pedro Juan Nuñez. Pero estos, y en concreto Núñez, pronto abandonaron esas filas para militar en otro bando.

Se alinea también claramente en la corriente clasicista con su Rhetorica Ecclesiastica, publicada en Lisboa en 1575 , el gran maestro y predicador en la corte de Felipe II, fray Luis de Granada, lo mismo que el profesor de Alcalá Martín de Segura, y por último, en el ámbito de los jesuitas, el abulense Bartolomé Bravo y el destacado maestro Cipriano Suárez, con cuyo manual se educaron generaciones de jóvenes hasta el siglo XVIII, como se desprende de los sucesivos planes de la Ratio Studiorum de la Compañía².

Me parece interesante destacar un común denominador en todos los citados, a excepción del aragonés Palmireno, y es que casi todos ellos son castellanos, salvo fray Luis, y que varios ejercieron su docencia en Alcalá.

La segunda corriente que se puede distinguir en el panorama retórico áureo es la que tiene su origen en las retóricas griegas post-aristotélicas que fueron recogidas por la cultura bizantina y que penetran con fuerza en la Italia del XV, promovidas por los humanistas emigrados a Italia desde Bizancio.

¿Cuáles son las diferencias doctrinales entre las doctrinas retóricas bizantinas y los paradigmas latinos? En lo que respecta a Hermógenes, y sintetizando mucho, porque contamos con excelentes ediciones y estudios sobre el autor de Tarso (Patillon 1988; Patterson 1970), podemos concretarlas en tres puntos:

1) En el Perí Stáseos, que influye enormemente en el método ramista, destaca la estructuración de la argumentación en torno a lo que se llamó «método de división».

2) Nos interesan más las ideas expuestas en el Perí Euréseos y, en concreto, la concepción de la narración ${ }^{3}$. El autor de Tarso entiende esta como una amplificación del tema, que en términos latinos llamaríamos propositio, obtenida por recursos que contravienen todas las reglas de la brevitas latina. Hermógenes fomenta una narración copiosa en la que cada circunstancia se amplifique con tres y hasta cuatro miembros (cuantos más mejor), porque en ello, afirma, se percibe 
el virtuosismo del orador. Asimismo aconseja dilatar lo narrado añadiendo lo omitido, es decir, lo que podría haberse dicho o hecho, y todo con muchos y variados miembros.

3) Por último, en el Perí Ideon, propone un sistema de 21 formas estilísticas frente a las tres latinas, cuyos medios expresivos quedaban minuciosamente establecidos y delimitados ${ }^{4}$. Son de sobra conocidos sus géneros y las distintas especies en las que se subdividen, así como los recursos para acercarse a estos ideales estilísticos; y por ello no vamos a repasarlos.

\section{IRRUPCIÓN DE LO BIZANTINO EN OCCIDENTE. LA APARICIÓN DEL RAMISMO}

Antes de deslindar qué seguidores tuvo el bizantinismo en España y quiénes fueron sus más acérrimos detractores, merece la pena repasar la irrupción de estas teorías en Occidente, porque nos llevará a valorar otra corriente doctrinal que disfrutó de un peso considerable en las últimas décadas del Quinientos y en el siglo XVII: el ramismo.

Monfasani (1999), en un trabajo ya clásico sobre la tradición retórica bizantina en el Renacimiento, centra el arranque del influjo bizantino en Occidente a finales del siglo XIV. En 1399, Manuel Crisoloras aparece como el gran maestro bizantino del Quinientos en su cátedra de Florencia. Crisoloras enseñó griego con eficacia y sus discípulos iniciaron oficialmente la captación renacentista de aquella tradición retórica: Leonardo Bruni, Patricio de Rustici, Guarino Veronese, etc. tradujeron discursos de Demóstenes y Esquines, de Arístides y de Isócrates. Junto con los ejemplos oratorios griegos, los humanistas aprendieron también a apreciar la retórica técnica preservada por esa misma tradición. Enseñando dicha retórica, los eruditos griegos emigrados podían, de algún modo, abrirse camino en la Italia humanista. Los ejemplos más señeros son -según Monfasani- Jorge de Trebisonda y Teodoro de Gaza. Nos interesa sobre todo el primero.

Trebisonda empieza a destacar en el ámbito humanístico cuando publica por primera vez en Venecia, en 1433-1434, su Rhetoricorum libri quinque. En este volumen, revelaba las doctrinas de las principales autoridades de la retórica bizantina, al tiempo que mostraba, con ejemplos de Cicerón, Virgilio, Livio y otros clásicos, que esta retórica era capaz de explicar los secretos de la elocuencia latina. Esto es, el maestro cretense supo integrar hábilmente las autoridades bizantinas, como Dionisio de Halicarnaso y, sobre todo, Hermógenes, con los grandes latinos. La retórica de Trebisonda tuvo éxito porque dio con la fórmula adecuada. Fue una Summa retórica artística en el XV italiano y una de las primeras obras producidas en Italia que traspasaron los Alpes.

En 1470, Guillaume Fichet -recuerda Monfasani- se quejaba en París de que en la Sorbona había un grupo de seguidores de Trebisonda. El hecho cierto

4. Véanse las traducciones de Consuelo Ruiz Montero (1993) y A. Pérez Royo(1991). 
es que, aunque Fichet se lamentara de ello, él mismo tomó algunas partes de la Retórica de Trebisonda para construir la suya y, al parecer, también ejemplares de la de Trebisonda circularon por París a finales del XV. A principios del XVI, el cretense se había convertido ya en una gran autoridad. Melanchthon justificó su Retórica breve como un medio de ahorrar a los estudiantes un gasto que, de otra manera, tendrían que asumir para comprar la Summa de retórica latina y griega de Trebisonda. No en vano, en España se implanta como libro de texto en 1511, en la recién fundada Universidad de Alcalá, esta misma Summa rhetoricae, y Alonso de Herrera lo justifica por ser un texto a caballo entre la prolijidad fastidiosa del tratado de Quintiliano y la excesiva brevedad ciceroniana.

Otro acontecimiento ocurrido a principios del Quinientos, y crucial en la historia del Renacimiento bizantino, fue sin duda la llamada edición aldina que se imprimió entre 1499 y 1513 en Venecia. Aldo Manuzio, con la ayuda de eruditos bizantinos, publica un corpus de oradores griegos y retóricos, incluyendo los mejores comentarios sobre Hermógenes. A estas ediciones siguieron otras importantes, en 1523 y 1536.

Como afirma Rico (1993: 77 y 85), a fines del XV los studia humanitatis se convirtieron en programa escolar y el maestro que los enseñaba ya no era el intelectual singular, sino un vulgar gramático, un tipo anodino. Fue entonces cuando «los humanistas de mayor talla tuvieron necesariamente que fijarse un nivel más alto» y el dominio de la lengua y literatura griegas les ofreció un mundo inagotable para resolver cuestiones filológicas y abordar temas científicos hasta entonces ignorados.

Pero no todos los textos que los bizantinos valoraban se incluyeron en los Rhetores Graeci y suscitaron el interés de los humanistas italianos sino que hubo una modificación de dicha tradición en el Renacimiento. Su pilar por lo que atañe a la doctrina retórica continuaba siendo Hermógenes que, ciertamente, tuvo una influencia importante en Occidente, pero que, según Monfasani, nunca llegó a alcanzar el predominio que había conseguido en Bizancio.

A mediados del XVI, dos importantes profesores y traductores de retórica, Conti en Italia y, sobre todo, Johan Sturm, profesor de Petrus Ramus, en el Norte, rubricaron nuevas versiones latinas de Hermógenes; pero, según Monfasani, Sturm fue el único que, de forma acusada, abogó por Hermógenes en el XVI y, al parecer, fue el responsable de las ediciones griegas de este autor, que empezaron a imprimirse en París, desde 1531.

Para Ong (1979: 232), de los tres autores que adoptan tempranamente el método lógico-dialéctico -Melachthon, Sturm y Ramus-, solo Sturm había trabajado con Agrícola, importó sus influencias a París y fue el primero en desarrollar el método. Con su llegada a París, en 1529, se empezaron a difundir las doctrinas de Agrícola y de Hermógenes. En 1530 y 1531, los Weschel publicaron cuatro manuales de retórica de Hermógenes en el griego original. Las cuatro obras fueron: el Ars rhetorica absolutissima, el Perí euréseos, el Perí ideon y el De metodo gravitatis. Estos trabajos adquieren particular significación, dado que los Weschel eran los editores de Sturm y de Ramus en París, del 
mismo modo que Sturm fue más tarde traductor y exégeta de otros tratados de Hermógenes (además del primero que, en su In partitiones Oratorias Ciceronis dialogi duo (1539), procuró combinar a Cicerón con Hermógenes).

Otro texto que, como hemos dicho, irrumpe en Occidente en el XV y que fue muy traducido en el XVI, fue el De compositione verborum de Dionisio de Halicarnaso. Este maestro, junto con Demetrio Falerio (Chiron 2001) y Aftonio ${ }^{5}$, fueron autoridades de cabecera para los bizantinos y los ejercicios escolares de este último gozaron de notable difusión en nuestro país ${ }^{6}$.

Hemos mencionado la influencia de Hermógenes a través de Jorge de Trebisonda en Johan Sturm. Pues bien, según Monfasani, Hermógenes está en el origen de la obsesiva corriente renacentista por el método; corriente que, huelga incidir en ello, conducirá finalmente a Descartes, pero que a corto plazo -y es lo que nos importa- lleva al amigo de Sturm y estudiante en París, Petrus Ramus, maestro a su vez de P. J. Núñez y que influyó de modo importante en Arias Montano, el Brocense y Baltasar de Céspedes.

Conviene seguir esas influencias porque "subsumido bajo el ramismo", dice el mismo autor -en unas palabras que cita y hace suyas Asensio (1981)«el método hermogeniano ejerció una profunda influencia en la educación occidental del XVII".

Es crucial en la doctrina dialéctica de Ramus, basada en el Perí Staseos hermogénico, la llamada doctrina del método, que Ramus dividió en método de doctrina y de prudencia ${ }^{7}$. El primero consistía en disponer las cuestiones haciéndolas descender desde los principios universales y generales, dividiéndolas dicotómicamente hasta llegar a las partes singulares. En este sistema-observaba Ramus- debe preceder siempre la definición y una especie de sumario general; después debe seguir la especial explicación por distribución de las partes, y por último la definición de cada una de las singulares, así como su clarificación por medio de ejemplos concretos.

En el método de prudencia hay que adecuar la disposición a las personas, hechos tiempos y lugares y, aunque el método anterior es válido -dice Ramusno siempre hay lugar para lo mejor y no siempre debe mantenerse la claridad de disposición, porque el público se aburre o el tema resulta desagradable etc.

No voy a detenerme en las cuestiones del método ramista y sus vínculos con lo hermogénico -Ong (1979), Merino (1992), Martín Jiménez (1997) y Luján Atienza (1999) lo han estudiado excelentemente-, sino que me centraré en la vertiente elocutiva y en intentar explorar, en primer lugar, las huellas que los aspectos formales del bizantinismo pudieron dejar en París. Después procuraré

5. Véase la traducción de los tres grandes autores de los Progymnasmata retóricos: Teón, Hermógenes y Aftonio en Reche (1991).

6. Autores como P. J. Núńez, A. Lulio, Alfonso de Torre, Juan de Guzmán y El Brocense escribieron y anotaron los Progymnasmata de Aftonio. Para una traducción y estudio más detallado del panorama retórico de estos ejercicios, véase Artaza (1997: 27-83).

7. Tomamos de Ong (1979: 245-247) la traducción de unas anotaciones que Ramus inserta al final del libro II de la obra de Omer Talon (Institutiones Oratoriae libri III, 1545). Para un seguimiento de las obras y ediciones de Ramus y Talon, véase el excelente catálogo de Green y Murphy (2006). 
afinar un poco el seguimiento de esas trazas por parte de nuestros maestros de retórica para poder determinar el grado de pureza de las mismas.

Para empezar, observamos algo de veras curioso. Según el minucioso análisis que Ong hace de la retórica ramista, constituida principalmente en torno a tropos y figuras, las doctrinas del profesor de París, aunque establecidas y concebidas geométricamente según su método, no se apartan desde 1545 de la tradición central de las retóricas latinas. No se puede decir -afirma Ong (1979: 273-274) - que haya en las ideas estilísticas de Ramus o de Talon nada ni furiosamente ciceroniano ni anti-ciceroniano. Catón, Cicerón y Quintiliano son las autoridades básicas de la disciplina y los dos últimos sus fuentes principales. No encontramos, por tanto, en la retórica de ambos el menor rastro de hermogenismo. Es decir, que la retórica de Ramus, por lo que respecta a tropos y figuras individuales, no se distingue comparativamente de otras retóricas clasicistas de su tiempo.

\section{INFLUENCIA DE LAS DOCTRINAS BIZANTINAS EN LOS RETÓRICOS ESPAÑOLES.}

\section{RAMISTAS, BIZANTINISTAS Y ANTIHERMOGÉNICOS}

¿Cuáles fueron las vías de introducción de lo bizantino en suelo español y los focos donde estas teorías prendieron con más fuerza?

Hemos dicho que la retórica de Trebizonda aparece tempranamente, en 1511, como libro de texto en Alcalá; pero creemos que su vigencia y difusión en esta Universidad fue muy corta. A los cuatro ańos posiblemente sería sustituida por el manual de Nebrija, que publica su obra en 1515 y que, por lo que afirma en el prólogo, para ahorrarse los disgustos sufridos con obras anteriores no pensaba separarse un milímetro de Aristóteles y de los latinos. Este pequeño foco de hermogenismo es único en el centro peninsular porque, como hemos visto, prácticamente todos los tratados que aparecen en el XVI en el centro de nuestro país siguen los esquemas que hemos llamado clasicistas.

Un panorama muy diferente es el que se observa en el Levante español, ya perfectamente iluminado por Luján Atienza (1999). Prácticamente todos los autores levantinos, en mayor o menor medida, han asimilado y hecho suyas las doctrinas ramistas y, sobre todo, en el caso de Núñez, las formas estilísticas del de Tarso. Precisamente un dato que llama la atención al estudioso de la retórica del XVI es el gran número de obras que se publicaron en Valencia y que un elevado número de los autores de retórica de ese siglo escribieran a orillas del Turia y alrededores. De los 17 autores de retóricas mayores del XVI, casi una tercera parte -cinco de ellos- o bien han nacido en Valencia-Vives, Núñez y Furió- o han nacido cerca -como es el caso de Sempere, que nació en Alcoy-o en Mallorca como Antonio Lulio.

Si nos preguntamos por las vías de penetración de esta corriente en suelo hispano, parece claro que, a pesar de la continuada tradición que vincula el Reino de Valencia con el de Nápoles, la influencia de las tesis bizantinas en los autores valencianos procede del Norte. 
¿Qué se puede decir con respecto a la impronta bizantina en las retóricas auspiciadas en Levante?

Lo primero que salta a la vista es la diferente estructura de la obra de estos autores frente a los llamados clasicistas. Todos ellos, excepto Núñez en su gran obra de $1578^{8}$, empiezan por la elocución, en lugar de hacerlo por las partes tradicionales que la retórica reservaba al contenido y a su disposición. Ese comienzo lo justifican casi todos. Vives abre la epístola dedicatoria9 diciendo que no hay cosa más propia del hombre prudente que usar de forma adecuada y hábil el lenguaje, que ningún otro trabajo requiere una mente más aguda ni sutil, un juicio más penetrante, ni mayor experiencia de las cosas que el uso de la retórica, que necesita previamente la inteligencia y la experiencia de la vida. ¿Con qué criterio - continúa Vives- le asignan algunos a la retórica un lugar en la enseñanza inmediatamente posterior a la gramática? ¿Cómo pueden ofrecer este arte a los adolescentes que no poseen conocimiento ni prudencia de la vida? ¿De dónde recogerá los argumentos el joven si desconoce la filosofía, el recuerdo de la Antigüedad, las costumbres de la vida y las tradiciones recibidas? Solo después de haber conseguido todo esto, se puede hablar con decoro y aprender la retórica. El maestro valenciano afirma con Aristóteles, autor al que cita $-\mathrm{y}$ ańadiríamos que con Dionisio de Halicarnaso, al que omite-, que no se puede enseñar a los jóvenes la filosofía moral, porque desconocen lo que es la vida, y que tampoco el adolescente es discípulo apto para la retórica, pues ignora las cosas y con esa laguna no puede entender en qué consiste este arte. Al comenzar el capítulo primero $^{10}$, después de afirmar que Dios dotó al hombre con la facultad del habla, declara que adaptará sus enseñanzas no al uso de una lengua determinada, sino a lo común de todas ellas, y que, aunque los antiguos se dedicaron a los géneros forenses, a cuestiones de deliberación, etc., él en cambio se consagrará a formar al hombre en toda clase de géneros, por lo que su doctrina no atenderá a lo que hay que decir, sino a cómo ha de decirse; por lo que comienza por el primer peldaño, que él considera que es la selección de palabras.

Furió, cuya obra Institutionum Rhetoricarum libri III aparece en Lovaina en 1554, también se aparta del trazado clásico. La retórica, para él, debe componerse de dos partes: la elocutio y la dispositio. En esto parece discrepar de su maestro, Petrus Ramus, y de Omer Talón, que entendían que las partes de la retórica eran la elocutio y la pronuntiatio; pero esa discrepancia es más aparente que real. Furió distingue una disposición dialéctica que difiere de la disposición retórica. La dialéctica vincula y adecúa constante y firmemente los argumentos con la cuestión que se desea probar, mientras que la dispositio retórica se ocupa de descubrir, ordenar y explicar las disciplinas; esto es: Furió asigna a la retórica la función del método que en Ramus correspondía a la dialéctica. La dialéctica

8. Núñez lo hace igualmente en una obrita en la que sigue a Omer Talon, las Institutiones Oratoriae collectae metódicos ex Institutionibus prioribus Audomari Talaei, Valencia 1774.

9. Juan Luis Vives, De ratione dicendi, Brujas, 1532. Para la edición espańola moderna, véase Camacho (1998).

10. Vives (1998: 11-15). 
proporciona los argumentos que la retórica coloca adecuadamente, no se ocupa de determinar la verdad o falsedad del caso, pero sí de su presentación, su campo de aplicación es ilimitado y no se circunscribe, como sostenía Aristóteles, al derecho civil ${ }^{11}$. La retórica es sencillamente la capacidad de hablar y de escribir y, como observa acertadamente Luján (1999: 428), «es la primera vez que, desde Vives, alguien dice explícitamente que el oficio del orador se cumple en la escritura».

Igual que su maestro francés, Furió distingue en la dispositio retórica dos géneros - uno de arte y otro de prudencia- y en ella trata de lo que considera la primera parte de la Retórica: la elocución, que define como «la doctrina de los ornamentos», que cambia el discurso vulgar por otro más elegante, y que esos ornamentos, que los griegos llaman esjémata -es decir, figuras- son como las luces o colores del discurso.

Sempere ${ }^{12}$, como el propio Furió, también apuesta metodológicamente en el íncipit de su manual, el Methodus Oratoria (1568), por la elocución; y lo hace basándose en la etimología de retórica. La voz -afirma- procede del verbo griego rheo, "fluir», en latín eloqui, por lo que el estudio de la retórica se corresponde con la elocución y debe preceder a la inventio, que es casi toda ella dialéctica y, por tanto, de estudio espinoso y difícil; y si Vives, Ramus y Talon disienten en el detalle de que la elocución sea parte propia de la retórica, y la inventio y la dispositio resulten ajenas, ¿por qué no colocar esta parte de la elocución en el primer lugar de su obra para seguir el único consenso de los retóricos?

El segundo punto interesante en la doctrina del revestimiento verbal es sin duda la importancia concedida por ellos al tratamiento del aspecto fónico de la palabra, pieza fundamental en el "cómo decir», por su capacidad para mostrar y poner la cosa ante los ojos. Vives nos da la clave en el Libro tercero del De ratione dicendi, al hablar de la descripción. Apunta allí que «es importante para poner la cosa ante los ojos no solo la significación de las palabras [...] sino el sonido mismo y la composición de las voces, como lo ilustra con muchos ejemplos Jorge de Trebisonda ${ }^{13}$.

Efectivamente, si bien es cierto que el conducto de estas doctrinas es la Retórica de Trebisonda, hay que decir que las doctrinas mismas proceden del De compositione verborum de Dionisio de Halicarnaso. Efectivamente, los tres valencianos citados tratan detenidamente y de modo similar, aunque con ciertas diferencias que en un estudio más detenido se podrían poner de relieve, el aspecto fónico de las palabras. No solo los autores citados dan una importancia capital al aspecto fónico de las palabras. Si nos adentramos en las retóricas barrocas, podría afirmarse lo mismo de otra interesante retórica valenciana del XVII, la de Francisco Novella, de 1641.

11. «Nulla enim vitae pars Rhetorica vacare potest», Furió Ceriol (1554: 108).

12. A. Sempere, Methodus Oratoria, J. Mey, Valencia, 1568; carta introductoria al lector: "Quare rectissime collegi, quan Graeci Rhetoricam vocant, nobis eloquentiam voce idem significante nominandam esse».

13. Vives, 1532. Trad. de Camacho (1998: 223). 
Si bien no pasan por alto la clasificación de las palabras atendiendo a su significación, esto es, a las connotaciones relativas a la dignidad de la cosa significada que hacen que unas palabras sean humildes y otras nobles, lo que realmente está en el foco de su interés es su qualitas sonorum y su quantitas (esto es: la longitud de sus sílabas o letras); o lo que es lo mismo, el sonum y el numerus, aspecto doctrinal estudiado magistralmente por Vega Ramos (1992).

El tercer punto que me parece importante destacar de la huella que las retóricas bizantinas dejaron en los valencianos es la doctrina hermogénica de los estilos. Pedro Juan Núñez es, sin duda, el mejor exponente de la evolución desde los esquemas ciceronianos, propios de su primera época, a los hermogénicos.

Núñez, como Trebisonda, ensaya una síntesis entre lo latino y lo bizantino; o, mejor dicho, lleva a cabo lo que Trebisonda intentó demostrar: que la retórica bizantina era una técnica que valía para interpretar a los autores latinos, sobre todo a Cicerón. De los discursos del Arpinate toma casi todos los ejemplos para ilustrar los preceptos del de Tarso y afirma que elige a Hermógenes entre los autores a los que pasa revista (Aristóteles, Teofrasto, Cicerón, Demetrio Falerio y Dionisio de Halicarnaso) porque fue el único que sobre la práctica de Demóstenes ilustró con ejemplos y preceptos claros cómo este orador había llegado a conseguir un estilo casi divino.

Pero el valenciano no reproduce a la letra el texto bizantino, sino que realiza algunas manipulaciones que merecen destacarse. Para empezar, reduce a siete los ocho capítulos que componían cada forma del decir del texto bizantino. Dedica una atención preferencial a la composición rítmica. Y reduce a uno los dos últimos ingredientes distinguidos por el de Tarso: la cláusula y el ritmo.

Tampoco sigue el orden de Hermógenes en la exposición de las formas, sino que dedica un lugar preferente entre ellas a la Magnificencia, que antepone a la Claridad por razones metodológicas, y sobre todo a una de las especies magníficas: la Abundancia, cuyo desarrollo casi triplica el número de páginas que dedica a las demás ideas (1578: 299 y Artaza 1997: 201-256).

El tratamiento que hace Vives de las formas del discurso es menos sistemático que el de Núńez. A ello dedica el libro segundo y, basándose en la imagen de que el discurso es como el hombre, en el que se puede distinguir un cuerpo con diversos aspectos y un alma, va tipologizándolo, pero sin revisar sistemáticamente los mismos aspectos en cada una de las variantes, sino limitándose simplemente a distinguir cuáles son las virtudes de cada tipo y los vicios o defectos que lo convertirían en indeseable.

Una lectura atenta del texto de Vives nos recuerda las múltiples menciones que Quintiliano hace al respecto a lo largo de su obra, sobre todo en el capítulo de la narración y en la moción de los afectos sobre los tonos en el decir. (Inst. Orat., IV, II, 56-59 y VI, II, 8-24)

Distinguimos entre las variantes estilísticas señaladas por Vives no solo los consabidos tres estilos latinos y sus comparaciones con el asiático, rodio y ático, sino varias formas de las destacadas por Núnez: como la magnifica, que requiere "palabras escogidas y elegantes de amplio y magnífico sonido, de frases copiosas y composición plena»; la bella y suave surgida de la armonía, con 
palabras propias de sonido dulce, sin iuncturae bruscas ni períodos muy largos; la abundante, que dice más de lo necesario; el discurso «sano" y el de "color natural», que recuerda el puro y distinto de Hermógenes con palabras claras, escogidas del uso común, pero correcto y limpio de asperezas, y el discurso vigoroso de sentencias breves, frases cortas y repetidas, etc.

Esta contaminación de lo latino y bizantino en una retórica temprana, pero innovadora, como es la de Vives, nos lleva a preguntarnos: ¿fue realmente importante en el panorama retórico español la influencia de la teoría hermogénica de los estilos? ¿Tuvo peso en la educación de los jóvenes y, en concreto, de los grandes escritores de los Siglos de Oro, o su relevancia fue más bien escasa y se redujo a un capítulo erudito y original que solo llegó a los alumnos de Núnez? ¿Estuvieron alguna vez los más de 20 estilos del Perí Ideon en pie de igualdad con las doctrinas latinas de los tres estilos, o fue algo que conocieron los estudiosos pero que no llegó a calar en la enseńanza y menos aún en el entrenamiento escolar?

Personalmente me inclino por esto último. Hasta donde he llegado en mis lecturas de los textos retóricos áureos, dos autores de manuales señeros y profesores de retórica rechazan abiertamente esta doctrina por estimarla farragosa e inútil. El primero es Alfonso García Matamoros, profesor de Alcalá de 1542 a 1572 (Artaza 1998: 134), y el segundo Juan Bautista Poza (S. J.), profesor de elocuencia del Colegio madrileño.

En un trabajo anterior (Artaza 2005: 46-47) llamé la atención sobre la asimilación que hacía García Matamoros en el De tribus dicendi generibus de los estilos del de Tarso a los tres géneros latinos. Decía allí el profesor de Alcalá (García Matamoros 1570: 56 ro) -y seguía en ello las huellas de Scaligero ${ }^{14}$, Minturno (1559: 549) y sobre todo de Vives- que las «formas del decir» hermogenistas deben considerarse más bien virtudes o cualidades del discurso que tipos de estilo, y que se las llame de un modo u otro, en su opinión importa poco, pues pueden asimilarse a los tres estilos latinos: humilde, medio y sublime. Citaba allí unas líneas de García Matamoros que reproduzco ahora:

De eisdem Loduvicus vives longo post temporis intervallo pertractavit, quas non dicendi formas sed orationis virtutes meritô quidem appellat.. Nam perspicuitas, dignitas, magnitudo, venustas, asperitas, vehementia, splendor, vigor, gravitas, simplicitas, et ceterae dicendi formae, quas Hermogenes divina quadam metodo persequitur, rectius virtutes orationis quam dicendi formae apellari debent. Quamquam sive orationis virtutes, sive formae dicendi vocentur, parum quidem mea sententia refert: dum eas dicendi formulas ad illa tria dicendi genera, tenue, mediocre, et summum referamus, quibus varium etiam styli habitum subiecimus.

14. Scaligero (1561: IV, 179 B). Allí reduce las formas del decir a tres: Antiloqua, Infima, Media quam aequabilem vocare liceat nobis; y cada una admite unos afectos propios del orador y otros comunes o compartidos con otras formas elocutivas, ya que para Scaligero todas estas ideas hermogénicas no son más que imágenes o modos de adecuarse el discurso a la realidad que imita y al estado de ánimo del orador. La función de las ideas es "Attribuere suam cuique naturam» (1561: 193 D -194 A). 
La siguiente gran retórica barroca neolatina que rechaza abiertamente la inclusión de la doctrina del Perí Ideon en la docencia es la de Juan Bautista Poza (S. J.), Rhetoricae compendium (1615), publicada en Madrid, en el taller de la viuda de Ildefonso Martín.

En el prólogo, el autor explica cómo ha reunido conocimientos dispersos en distintos escritores intentando conjugar brevedad con claridad; y al mencionar sus fuentes, afirma que se va a ocupar de Aristóteles con menos detención, porque sus libros resultan difíciles para los que no cuentan con la suficiente erudición y rudimentos de dialéctica.

Tampoco tributa grandes alabanzas a Cicerón, al que, si bien reconoce que es admirable en el ejercicio de su arte, no le parece que haya sido tan genial en la transmisión por escrito de sus conocimientos. Repasa y critica todas y cada una de las obras del Arpinate que, al parecer, no le dejan satisfecho, y se acaba decantando por Quintiliano, al que confiesa que sigue fielmente.

Respecto a la gran fuente grecobizantina que es Hermógenes de Tarso, Poza añade algo que creo que ayuda a contestar las preguntas que nos acabamos de hacer sobre la difusión que pudieron tener las doctrinas hermogenistas en España. El profesor jesuita declara abiertamente que debe mucho a Hermógenes, al que reconoce haber tratado con mucha finura las tres partes de la retórica (inventio, dispositio y elocutio), pero opina que, si se hubiera dedicado a ello durante más tiempo, habría escrito con mayor claridad, porque realmente sus obras apenas las entienden los mejores y más ilustrados maestros ${ }^{15}$.

Reconoce que también estima mucho a Trapezuntio, en el que dice que se encuentran casi todas las doctrinas de Cicerón y Hermógenes, aunque, según Poza, omitió muchas otras, especialmente las que tienen que ver con el conocimiento de los afectos.

Después de este periplo, siguiendo el rastro del hermogenismo y su influencia en la educación, podemos concluir que estamos de acuerdo con Monfasani (1999) en que, subsumidas bajo el ramismo las doctrinas del de Tarso, ejercieron una profunda influencia en la educación de los estudiantes de los Siglos de Oro ${ }^{16}$; pero, al parecer, al menos en lo elocutivo, no por medio de las teorías estilísticas del Perí Ideon, sino más bien por las relativas a la invención -recordemos la copiosidad elocutiva que propugna en la narración, absolutamente incompatible con las enseñanzas tradicionales sobre la primera cualidad que debe presidir esta parte del discurso: la brevedad ${ }^{17}-y$, sobre todo, por las doctrinas del método para la exposición y prueba de los argumenta.

15. "Verum ipsius scripta ab optimis et literatis magistris vix intelleguntun", carta introductoria al lector; Poza (1615: 5r).

16. Monfasani (1999).

17. George A. Kennedy, en sus notas al texto griego de Hermógenes sobre la invención y el método editado por Hugo Rabe, opina que esta copiosidad aconsejada en la narración obedece a un deseo del de Tarso de proporcionar a los estudiantes técnicas y fórmulas para conseguir pericia, riqueza y agilidad en la oratoria. Véase Kennedy (2005: 51). 


\section{Bibliografía}

Asensio, Eugenio, 1978, "Ciceronianos contra erasmistas. Dos momentos. (15281560)», Revue de Littérature Comparée, 206, pp. 136-148 [Homenaje a Marcel Bataillon].

Asensio, Eugenio, 1981, «Ramismo y crítica textual en el círculo de Fray Luis de León», en V. García de la Concha (ed.), Fray Luis de León [Actas de la I Academia Literaria Renacentista], Salamanca, Universidad de Salamanca, pp. 47-76.

Artaza, Elena, 1988, El ars narrandi en el siglo XVI español, Bilbao, Universidad de Deusto, 360 p.

Artaza, Elena, 1997, Antología de textos retóricos españoles del siglo XVI, Bilbao, Universidad de Deusto, 277 p.

Artaza, Elena, 2005, «Los estilos retóricos en los discursos de los personajes literarios», en El personaje literario y su lengua en el siglo XVI, en Consolación Baranda Leturio y Ana Vián Herrero (eds.), Madrid, Instituto Universitario Menéndez Pidal, Ed. Complutense, pp. 41-64.

Blanco, Mercedes, 2006, "La idea del estilo en la Espańa del siglo XVII», en Actas del VII congreso de la AISO, pp. 17-29.

Cerdán, Francis, 1993, «La emergencia del estilo culto en la oratoria sagrada del siglo XVII», Criticón, 58, pp. 59-68.

Chiron, Pierre, 2001, Un rhéteur méconnu: Démétrios (Ps. Démétrios de Phalére). Essai sur les mutations de la théorie du style à l'époque hellénistique, París, Vrin, 635 p.

Egido, Aurora, 1986, "La poética del silencio en el Siglo de Oro. Su pervivencia», Bulletin Hispanique, 88, 1-2, pp. 93-120.

Furió Ceriol, Fadrique, 1554, Institutionum Rhetoricarum libri III, Lovaina, Ex Officina Stephani Gualtheri et Ioannis Batheni.

Gallego Barnés, 1982, Andrés, Juan Lorenzo Palmireno (1525-1579). Un humanista en la Corte General de Valencia, Zaragoza, Institución Fernando el Católico, 303 p.

García Matamoros, Alfonso, 1570, De tribus dicendi generibus sive de recta informandi stily ratione comentarius, Alcalá de Henares, Andrés Angulo.

García Rodríguez, Javier, 2002, "Aproximación a la retórica del siglo XVII: actio y pronuntiatio en el Epitome de la Elocuencia Española de F. de Artiga (1692)», Alazet, 14, pp. 257-265.

Green, Lawrence D. y Murphy, James J., 2006, Renaissance rhetoric short-title catalogue, 1460-1700, Aldershot, Ashgate, 467 p.

Hermogène, L'art rhétorique, traduction française intégrale, introduction et notes par Michel Patillon, 1997, Paris-Lausanne, L’âge d'homme, 640 p.

Hermógenes, Sobre los tipos de estilo, Introducción, traducción y notas de Antonio Sancho Royo, 1991, Sevilla, Universidad de Sevilla, 214 p.

Hermógenes, Sobre las formas de estilo, introducción, traducción y notas de Consuelo Ruiz Montero, 1993, Madrid, Gredos, 344 p.

Isasi Martínez, Carmen, 1997, «Traducción y Retórica. Notas para la Historia de la traducción en España», Livius, 10, pp. 77-90. 
Kennedy, George A., 2005, Invention and Method: Two Rethorical Treatises from the Hermogenic corpus (Writings from the Greco-Roman World), Atlanta, Society of Biblical Literature \& Leiden, Brill, 271 p.

López. Grigera, Luisa, 1994, La retórica en los Siglos de Oro. Teoría y Práctica, Salamanca, Ediciones de la Universidad de Salamanca, 287 p.

Luján Atienza, Ángel Luis, 1999, Retóricas españolas en el XVI: el foco de Valencia, Madrid, CSIC, 336 p.

Mañero, David, 2009, «Del concepto de decoro a la teoría de los estilos: consideraciones sobre la formación de un tópico clásico y su pervivencia en la literatura española del Siglo de Oro", Bulletin Hispanique, CXI, 2, pp. 375-387.

Martín Jiménez, Alfonso, 1997, Retórica y literatura en el siglo XVI. El Brocense, Valladolid, Universidad de Valladolid, 187 p.

Martín Jiménez, Alfonso, 2000, «El Quijote de Cervantes, el Quijote de Avellaneda y la retórica del Siglo de Oro», Edad de Oro, XIX, pp. 171-187.

Merino Jerez, Luis, 1992, La pedagogía en la retórica del Brocense, Cáceres, Universidad de Extremadura, 322 p.

Minturno, Antonio Sebastiano, 1559, De Poeta libri sex, Venecia, apud Franciscum Rampazetum.

Monfasani, John, 1976, George of Trebizond. A Bibliography and a Study of his Rhetoric and Logic, Leyden, E. J. Brill, 414 p.

Monfasani, John, 1999, «La tradición retórica bizantina en el Renacimiento», en J. Murphy (ed.), La elocuencia en el Renacimiento, Madrid, Visor, pp. 211-225.

Monumenta Historica Societatis Iesu. Monumenta paedagogica societatis Iesu, 1965-1974, edidit ex integro refecit novisque textibus auxit Ladislaus Lukács S.I. vols. 92, 107 y 108, Roma.

Núñez, Pedro Juan, 1578, Institutiones Rhetoricae ex progymnasmatis potissimun Aphtonii atque ex Hermógenis arte, Barcelona.

Ong, Walter J., Ramus, 1979, Method and the Decay of the Dialogue, New York, Octagon, 408 p.

Patillon, Michel, 1988, La théorie du discours chez Hermogène le rhéteur. Essai sur la structure de la Rhétorique ancienne, París, Les Belles Lettres, 412 p.

Patterson, Annabel M., 1970, Hermogenes and the Renaissance. Seven ideas of Stile, Princeton University Press, 240 p.

Poza, Juan Bautista de, 1615, Rhetoricae compendium..., Matriti, apud Viduam Ildefonsi Martini.

Rico, Francisco, 1993, El sueño del humanismo. De Petrarca a Erasmo, Madrid, Alianza, 202 p.

Scaligero, Giulio Cesare, 1561, Poetices libri septem, Lyon, apud Antonium Vincentium.

Teón, Hermógenes y Aftonio, 1991, Ejercicios de Retórica, introducción, traducción y notas de M. ${ }^{a}$ Dolores Reche Martínez, Gredos, Madrid, 273 p.

Vega Ramos, María José, 1992, El secreto artificio. Maronolatría y tradición pontaniana en la Poética del Renacimiento, Madrid, CSIC, 380 p.

Vives, Juan Luis, 1532, El arte retórica / De ratione dicendi, ed. de Ana Isabel Camacho, 1998, Barcelona, Anthropos, 343 p. 